\title{
Clinical Significance of Methylation and Reduced Expression of the Quaking Gene in Colorectal Cancer
}

\author{
NORIKO IWATA ${ }^{1}$, TOSHIAKI ISHIKAWA ${ }^{2}$, SATOSHI OKAZAKI ${ }^{1}$, KAORU MOGUSHI $^{3}$, \\ HIRONOBU BABA ${ }^{1}$, MEGUMI ISHIGURO ${ }^{4}$, HIROTOSHI KOBAYASHI ${ }^{1}$, HIROSHI TANAKA ${ }^{3}$, \\ TATSUYUKI KAWANO ${ }^{1}$, KENICHI SUGIHARA ${ }^{2}$ and HIROYUKI UETAKE ${ }^{2}$ \\ ${ }^{1}$ Division of Surgical Gastroenterology, ${ }^{2}$ Division of Surgical Specialties, \\ and ${ }^{4}$ Department of Translational Oncology, Graduate School of Medical and Dental Sciences, \\ and ${ }^{3}$ Department of Systems Biology, Graduate School of Biochemical Science, \\ Tokyo Medical and Dental University, Tokyo, Japan
}

\begin{abstract}
Background: This study investigated abnormal methylation in colorectal cancer $(C R C)$ and the potential role of the Quaking RNA-binding protein (QKI) gene in tumorigenesis. Materials and Methods: Oligonucleotide microarray expression profiling was carried out on a panel of primary CRC specimens $(n=17)$ and CRC cell lines $(n=5)$, followed by methylation analysis using methylation-specific polymerase chain reaction. QKI expression levels were assessed in 156 primary CRCs by qRT-PCR and immunohistochemistry. Results: Low QKI expression was observed in $47.7 \%$ in CRCs. QKI promoter methylation was detected in $32.1 \%$ of patients with CRC, and in these patients mRNA expression in tumor tissue was significantly downregulated compared to matched normal tissues $(p=0.049)$. There was a significant relationship between low QKI expression and recurrence after surgery $(p=0.004)$. Low $Q K I$ expression was an independent risk factor for recurrence after surgery in 153 patients with CRC without distant metastases $(p=0.036)$. Conclusion: Patients with tumors expressing low levels of QKI experienced significantly higher rates of tumor recurrence after curative surgery and worse prognoses. Methylation of the QKI promoter and concomitant reduced expression of QKI mRNA may be important for CRC initiation and progression. Loew QKI expression may be a useful clinical biomarker for predicting recurrence and prognosis.
\end{abstract}

Correspondence to: Toshiaki Ishikawa, Division of Surgical Specialties, Tokyo Medical and Dental University, Graduate School of Medical and Dental Sciences, 1-5-45 Yushima, Bunkyo-ku, Tokyo, 113-8519, Japan. Tel: +81 358035261, e-mail: ishi.srg2@tmd.ac.jp

Key Words: Colorectal cancer, Quaking RNA-binding protein gene, $Q K I$, tumor-suppressor gene, methylation, prognostic factor.
Colorectal cancer (CRC) is one of the best understood neoplasms from a genetic perspective, yet it remains the second most common cause of cancer-related death. Although the diagnosis and treatment of CRC has significantly improved during recent decades, leading to a substantial reduction in cancer-related mortality (1), CRC continues to be a major public health problem worldwide.

It is now well established that widespread epigenetic changes, including alterations in DNA methylation profiles relative to non-neoplastic tissue, are a characteristic of many cancer types $(2,3)$. Epigenetic alterations, such as aberrant DNA hypermethylation are now recognized as one of the crucial mechanisms underlying tumor-suppressor gene inactivation in cancer (4). In addition to identifying genes with a potential role in oncogenesis, methylation of specific gene promoters is a hallmark of different cancer types and can be used in cancer diagnosis and classification (5). For example, in CRC, coordinated methylation of a specific set of genes classifies cancers as the $\mathrm{CpG}$ island methylator phenotype (CIMP), and this classification is associated with B-Raf proto-oncogene BRAF mutations (6).

Advances in genome-wide methylation analysis technology have revealed that methylation regulates many genes that control apoptosis, and cell-cycle regulation of other fundamental cellular processes $(7,8)$. DNA microarray and high-throughput DNA sequencing are two powerful techniques that enable the large-scale analysis of DNA methylation (9-12). In this study, we searched for clinically significant tumor-suppressor genes in CRC by screening for candidate genes suspected to be silenced by DNA methylation using microarray analysis. We focused our study on the Quaking RNA-binding protein gene ( $Q K I)$ gene, which encodes a RNA-binding protein that was reported to be inactivated in CRC (13), and demonstrated the clinical significance of $Q K I$ expression in CRC specimens. 


\section{Materials and Methods}

Clinical sample collection. We collected primary CRC specimens and matched corresponding normal mucosa from 156 patients who had undergone surgery at Tokyo Medical and Dental University Hospital (Tokyo, Japan) between 2005 and 2009. All patients provided written informed consent, and the study was approved by the Institutional Review Boards of all institutions involved (approval number: 831). Clinical data were obtained from the medical records of each patient. The patients were monitored every 3 months after surgery, and their median follow-up was 60 months.

Cell culture and demethylation treatment of cell lines. We used five CRC cell lines (RKO, HCT116, HT29, colo320DM, SW480). These were purchased through the American Type Culture Collection (Manassas, VA, USA) or Cell Resource Center for Biomedical Research, Tohoku University (Miyagi, Japan), minimum essential medium, Dulbecco's modified Eagle's medium, or McCoy's 5A medium (Gibco, Carlsbad, CA, USA) containing $10 \%$ heatinactivated fetal bovine serum, 100 units $/ \mathrm{ml}$ of penicillin, $100 \mu \mathrm{g} / \mathrm{ml}$ of streptomycin, $10 \mathrm{mM}$ of HEPES and $1.0 \mathrm{mM}$ of sodium pyruvate and incubated at $37^{\circ} \mathrm{C}$ in $5 \% \mathrm{CO}_{2}$. Cells were plated in culture plates on day -2 . On day 0 , the culture medium was removed and new medium containing $0.5 \mu \mathrm{M}$ of the DNA methylase inhibitor 5aza-2-deoxycytidine (5-aza-DC) was added. The cells were treated with $0.5 \mu \mathrm{M}$ of 5 -aza-DC for $72 \mathrm{~h}$, according to a previous report (14). The cells were then rinsed twice with fetal bovine serum-free medium and collected with trypsin-ethylenediaminetetra-acetic acid after $72 \mathrm{~h}$ of 5 -aza-DC treatment.

Oligonucleotide microarray analysis. RNA from five human CRC cell lines (RKO, HCT116, HT29, colo320DM, SW480) was extracted before and after treatment with 5-aza-DC. Matched samples of primary cancer and adjacent normal tissues were obtained from 17 patients with CRC, and total RNA was extracted from each using a RNeasy mini-kit (Qiagen, Hilden, Germany). The integrity of the total RNA was assessed using an Agilent 2100 BioAnalyzer (Agilent Technologies, Palo Alto, CA, USA). All samples had an RNA integrity number of at least 5.0 prior to gene-expression analysis. Complementary RNA was prepared from $2 \mu \mathrm{g}$ cell line total RNA, and $100 \mathrm{ng}$ tissue sample total RNA by one-cycle and two-cycle target labeling, respectively, using a control reagents kit (Affymetrix, Santa Clara, CA, USA). Hybridization to Human Genome (HG) U133 Plus 2.0 arrays (Affymetrix) and signal detection were performed according to the manufacturer's protocol. The gene -expression data are deposited in the Gene Expression Omnibus (http:// www.ncbi. nlm.nih.gov/geo/) under accession number GSE32323.

For each of the 54,613 probes on the HGU133 Plus 2.0 array, fold-change (FC) values were calculated using R2.11.1 statistical software together with a Bioconductor package (R Foundation for Statistical Computing, Vienna, Austria) as previously described (15).

Probe sets from cell lines were selected using a combination of the following criteria: i) FC $>2.0$ compared with the CIMP RKO cell line, and ii) up-regulation of gene expression in at least two CRC cell lines. For the paired clinical samples, probe sets were selected for $\mathrm{FC}$ of normal compared to tumor tissue $(\mathrm{N} / \mathrm{T})>1.5$ (i.e. those with higher expression in normal than tumor tissue) (Figure 1).

$m R N A$ expression assay. We assessed the QKI mRNA expression level in each cell line and clinical sample by quantitative Reverse
Transcription Polymerase Chain Reaction (qRT-PCR). Total RNA was extracted using an RNeasy mini kit (Qiagen) and cDNA was synthesized using the High Capacity cDNA Reverse Transcription kit (Applied Biosystems, Foster City, CA, USA) according to the manufacturer's instructions. cDNA was then amplified by polymerase chain reaction PCR using a fluorescence-based real-time detection method on an ABI Prism 7300 Real-time PCR System according to the manufacturer's protocol. TaqMan $Q K I$ and $\beta$-actin (ACTB) Gene Expression Assays-on-demand (QKI Assay ID Hs00287641_m1, ACTB Assay ID Hs99999903_ml; Applied Biosystems) were used for qRT-PCR. $Q K I$ mRNA expression levels in each sample were normalized to those of $A C T B$ as an internal standard. Relative quantification of $Q K I$ mRNA expression was calculated by the $\Delta \Delta \mathrm{Ct}$ method using SDSv1.2 with RQv1.0 software (Applied Biosystems). Each analysis was performed in triplicate.

Methylation analysis. Total genomic DNA was isolated from both tumor and normal colon epithelium samples using the phenol/chloroform method. Bisulfite treatment was performed using an EpiTect Plus DNA Bisulfite kit (Qiagen) according to the manufacturer's instructions. Bisulfite-modified DNA was then used as template DNA for PCR amplification with the PCR primers corresponding to the region affected by the methylation. Methylated primer sequences were based on previous reports (13). Methylationspecific PCR (MSP) was performed using an EpiTect MSP kit (Qiagen). PCR conditions were as follows: $95^{\circ} \mathrm{C}$ for $5 \mathrm{~min}, 35$ cycles of $95^{\circ} \mathrm{C}$ for $30 \mathrm{~s}, 56^{\circ} \mathrm{C}$ for $30 \mathrm{~s}, 72^{\circ} \mathrm{C}$ for $30 \mathrm{~s}$, and finally 5 min at $72^{\circ} \mathrm{C}$. Epitect control DNA (human), methylated/ unmethylated and bisulfite-converted gDNA (Qiagen, Hilden, Germany) was used as a positive control for the methylated/unmethylated determinations. After amplification, PCR products were electrophoresed on a $1.5 \%$ agarose gels.

Immunohistochemistry. IHC studies of QKI expression were conducted using FFPE tissue blocks from each of 156 patients. Paraffin-embedded tumor tissue sections were deparaffinized in xylene and rehydrated in graded alcohol. Antigen retrieval was performed by autoclave sterilization in $0.01 \mathrm{M}$ sodium citrate buffer (pH 9.0) for $30 \mathrm{~min}$. Endogenous peroxidase activity was quenched with $3 \%$ hydrogen peroxide in methanol for $15 \mathrm{~min}$. Sections were blocked in goat serum for $30 \mathrm{~min}$ at room temperature, and incubated with a 1:100 dilution of rabbit antibody to QKI (IHC00574, 9444, AAH19917.1; BETHYL, Montgomery, AL, USA) at $4^{\circ} \mathrm{C}$ overnight, then sections were incubated with Histofine simple stain MAX-PO (MULTI; Nichirei Bioscience, Tokyo, Japan) secondary antibody for $30 \mathrm{~min}$ at room temperature. QKI staining was visualized after incubation with 3,3'-diaminobenzidine tetrahydrochloride (Nichirei Bioscience) and was followed by counterstaining with hematoxylin. Phosphate-buffered saline was used instead of the primary antibody as a negative control. Staining results were assessed by two pathologists independently.

Staining intensity and proportion were both considered in the scoring system (Figure 2): Intensity grade (IG): Negative: 0; weak staining: 1; moderate staining: 2; strong staining: 3. Extent grade (EG): $<10 \%$ positively stained: $1,10-50 \%$ positively stained: 2 , $>50 \%$ positively stained: 3 . Then the immunoreactive score (IRS) was calculated as: $\mathrm{IRS}=(\mathrm{IG} 0 \times \mathrm{EG})+(\mathrm{IG} 1 \times \mathrm{EG})+(\mathrm{IG} 2 \times \mathrm{EG})+$ (IG3 $\times$ EG).

Statistical analysis. All analyses were performed with the SPSS software package version (version 17.0;SPSS Inc., Chicago, IL, 
5-Aza-dC-treated CRC cell lines (0.5 $\mu \mathrm{M}$ for $72 \mathrm{~h})$

\section{Oligonucleotide microarray (Human Genome U133 Plus 2.0) 54613 Genes}

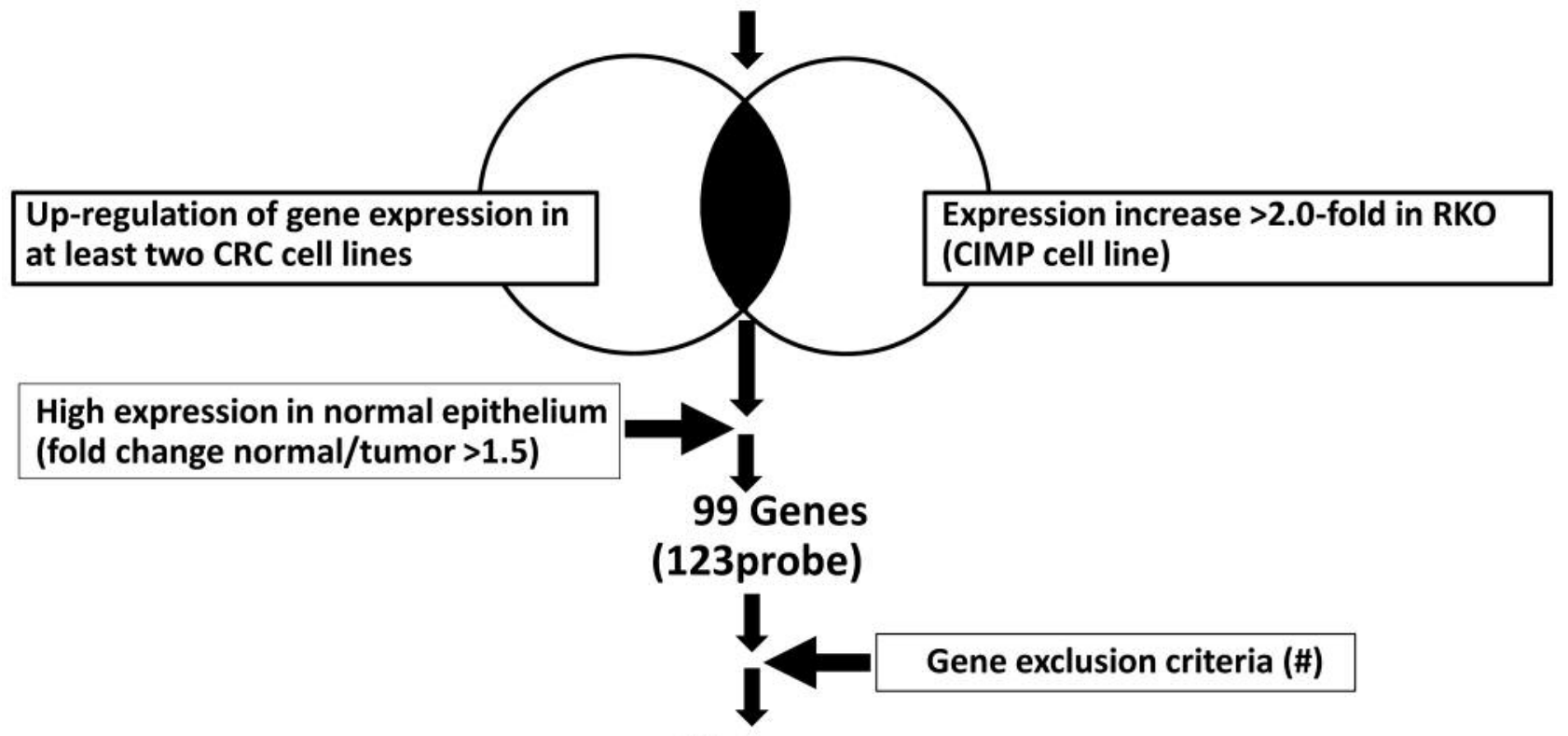

11 Genes

Figure 1. Outline of selection of candidate genes in colorectal cancer. 5-Aza-DC: 5-aza-2-deoxycytidine; CIMP: CpG island methylator phenotype.

USA). To estimate the differences between groups, the Chi-square test, Fisher's exact test, and Mann-Whitney $U$-test were used where appropriate. The IRS was used to classify the samples into two groups depending on a cut-off score of 5.5 based on the ROC curve analysis (Figure 3). Survival curves were plotted according to the KaplanMeier method, and differences between the curves were analyzed by log-rank test. Univariate and multivariate analysis for risk factor of postoperative recurrence were undertaken using the logistic regression model. A value of $p<0.05$ was considered as significant.

\section{Results}

Candidate genes suppressed by DNA methylation. We treated colo 320DM, HCT116, HT29, RKO and SW480 CRC cell lines with 5-aza-DC and compared mock- and treated cell lines using microarray analysis to identify genes that were reactivated in response to demethylation (methodology summarized in Figure 1). Genes which were re-expressed by more than 2.0-fold after 5-aza-DC treatment compared with the CIMP RKO CRC cell line, and up-regulated more than 1.5-fold in cancer tissues compared to normal mucosa were selected as candidate genes. In this way, we identified 99 genes (123 probes) that appeared to be suppressed by DNA methylation. We examined the published literature for additional analysis of these genes. In order to identify epigenetically affected genes with methylation, we first excluded genes in neoplasm not affected by methylation (51 genes). In addition, we removed genes with high or unknown expression in neoplasm (14 genes), genes with hypomethylation or unknown methylation status in neoplasm (23 genes). Finally, a list of 11 genes was determined which includes genes previously reported as being hypermethylated in neoplasms (Table I), some of which have tumorsuppressor functions, such as RASSF2 (16-18) and KLF4 (19, 20) and $A K A P 12$ (21). Among these candidate genes, we focused on $Q K I$ because it was reported to be downregulated in $\operatorname{CRC}(13,22,23)$, but the clinical significance and the mechanism of inactivation remain unclear.

$Q K I$ expression in primary CRC specimens. We investigated the association between methylation status and gene expression in tumor and normal tissue to determine whether the down-regulation of $Q K I$ expression was related to hypermethylation of the promoter. The methylation status of QKI in 115 CRC specimens was investigated by MSP (Table 
a



C

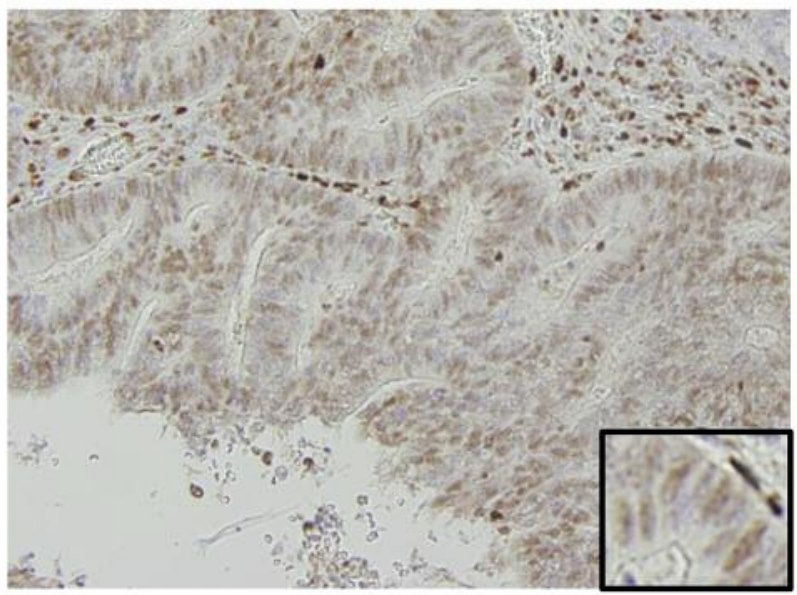

b

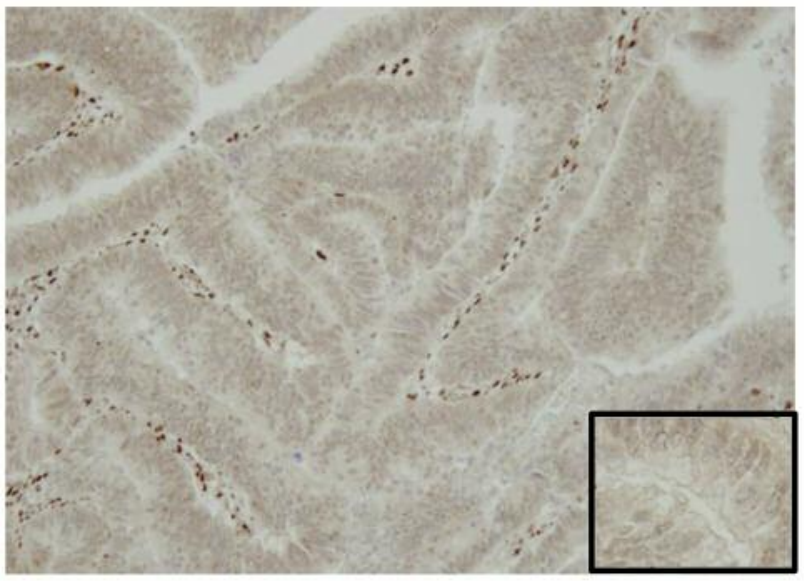

d

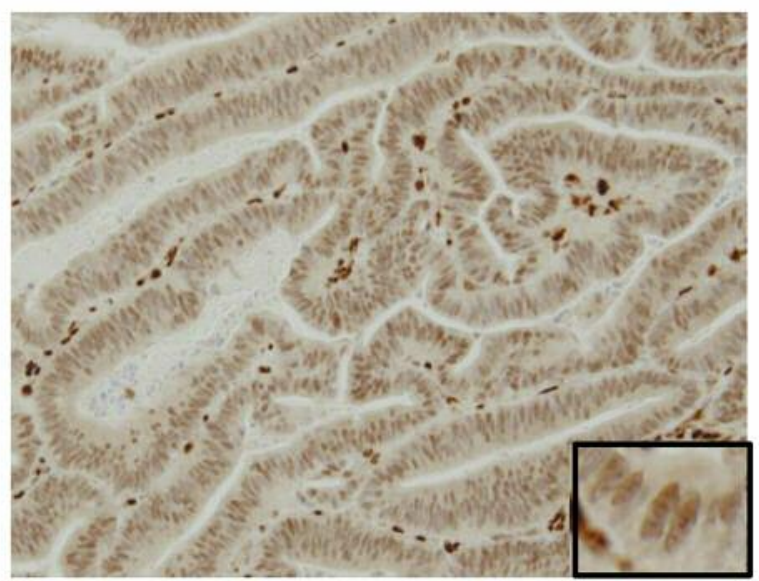

Figure 2. Representative immunohistochemical analysis showing negative (a), weak (b), moderate (c) and strong (d) staining of Quaking RNAbinding protein expression in primary colorectal cancer specimens. Main images, $\times 40$, insets: $\times 200$.

II and Figure 4) and $Q K I$ promoter methylation was detected in $32.2 \%$ of specimens (Table II). QKI mRNA expression was significantly down-regulated in CRC specimens with promoter methylation compared with normal tissue $(p=0.049)$. On the other hand, $Q K I \mathrm{mRNA}$ expression levels in normal tissue and unmethylated CRC specimens were not significantly different $(p=0.397)$ (Figure 4).

QKI protein expression in CRC specimens. Following antibody optimization and staining, the cellular localization of the $Q K I$ protein was investigated using cancer tissue from 156 patients. $Q K I$ protein was observes in the nucleus of cancer cells. The staining tended to be weak at the invasive tumor front, however, the entire tumor cross-section showed heterogeneous staining (Figure 2). Therefore, we assessed the entire tumor crosssection, and graded the $Q K I$ expression level using the IRS.

The median of IRS was 6 (range $=0-14$ ). The cutoff value of IRS was 5.5, as determined from ROC curve for predicting recurrence after surgery (Figure 3 ). The patients

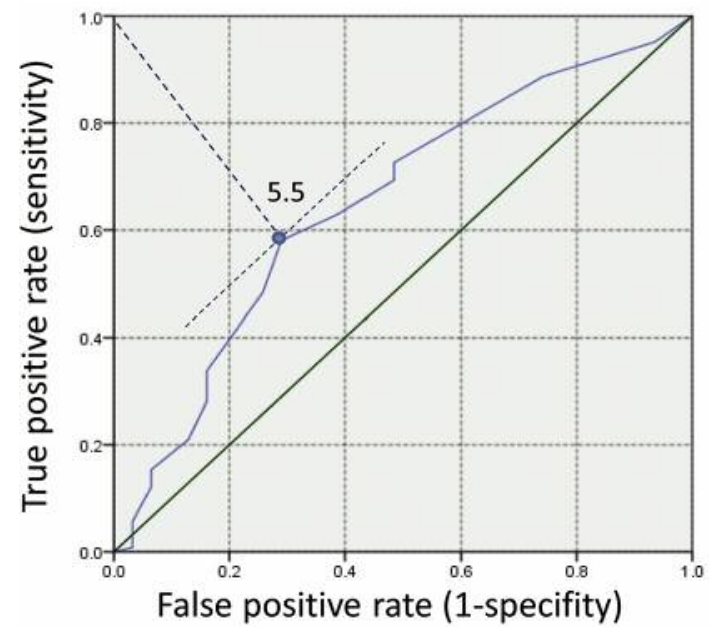

Figure 3. Receiver operating characteristic (ROC) curve of immunoreactivity score for detecting colorectal cancer recurrence after surgery. Based on the drawn ROC curve, the cut-off point for IRS was 5.5. area under the ROC curve: $0.651, p=0.009$. 
a

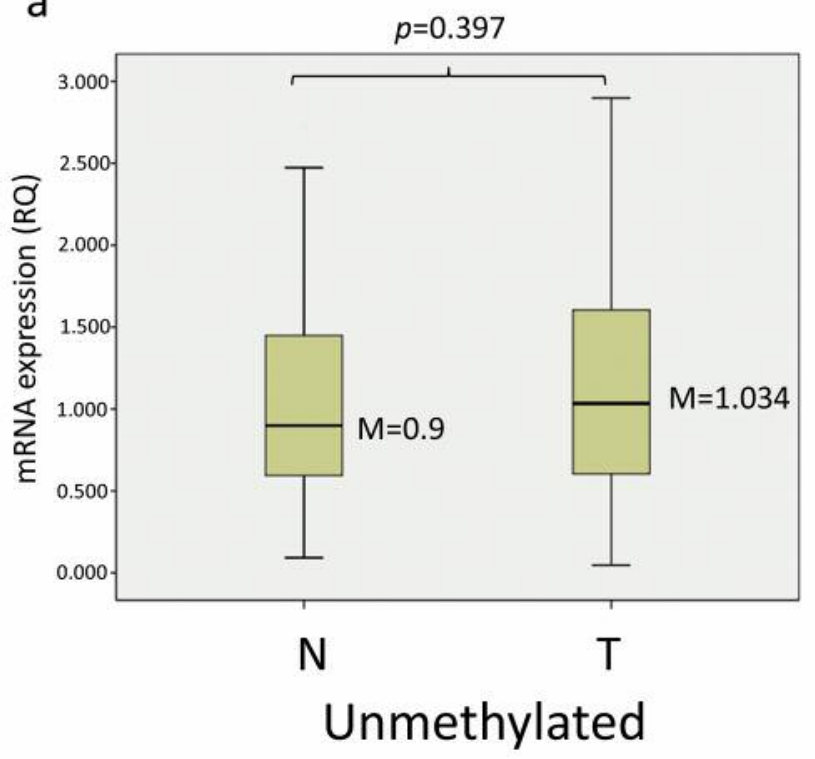

b

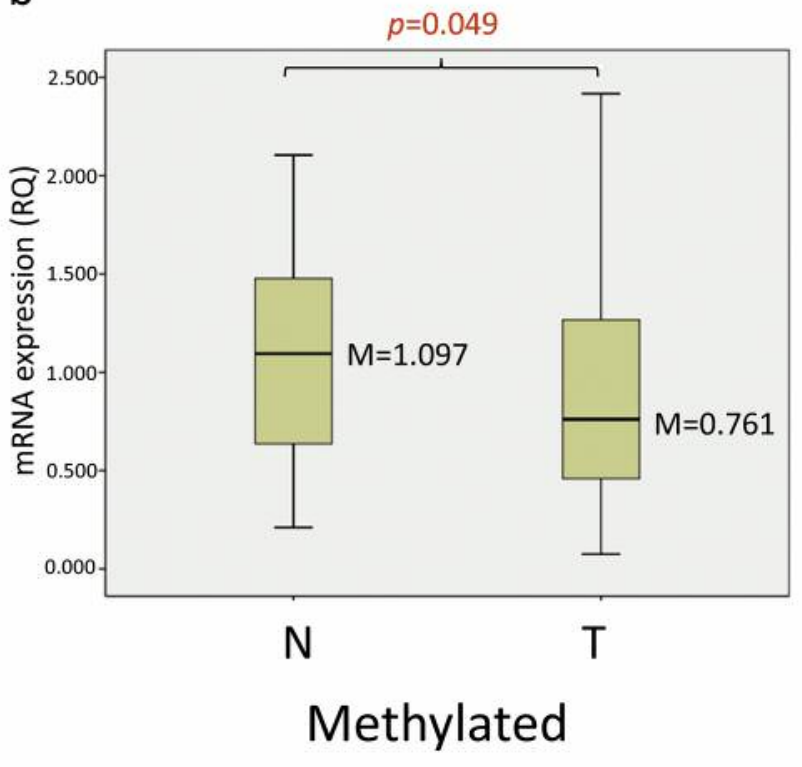

Figure 4. Box and whiskers plot of the methylation status and mRNA expression levels of Quaking RNA-binding protein gene (QKI) in 115 colorectal cancer specimens $(T)$ and normal mucosa $(N)$ with unmethylated $(a)$ and methylated (b) QKI by Mann-Whitney U-test. M: Mean.

a

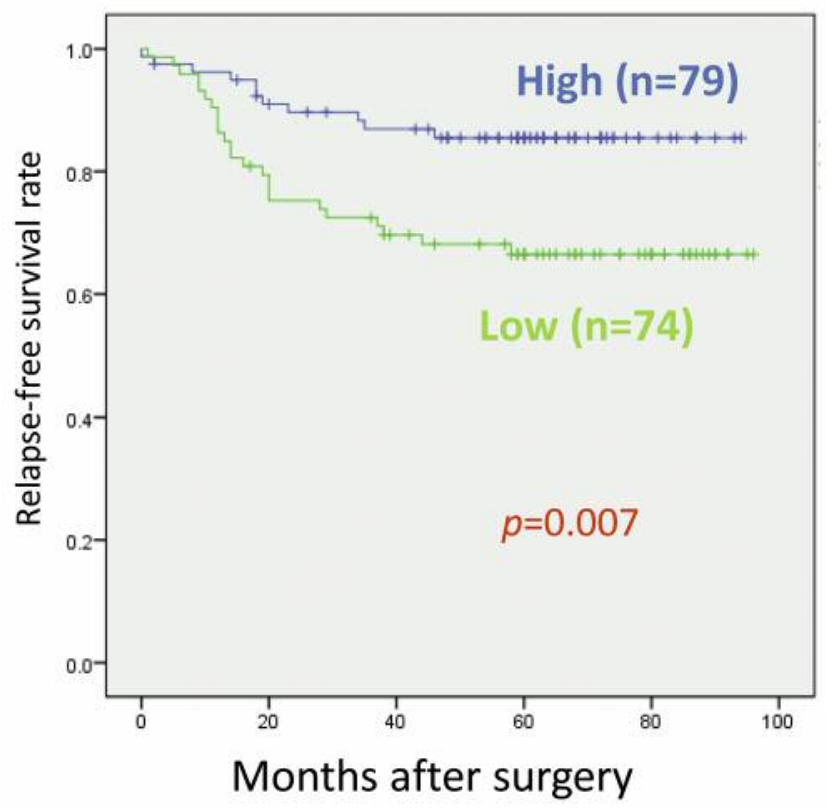

b

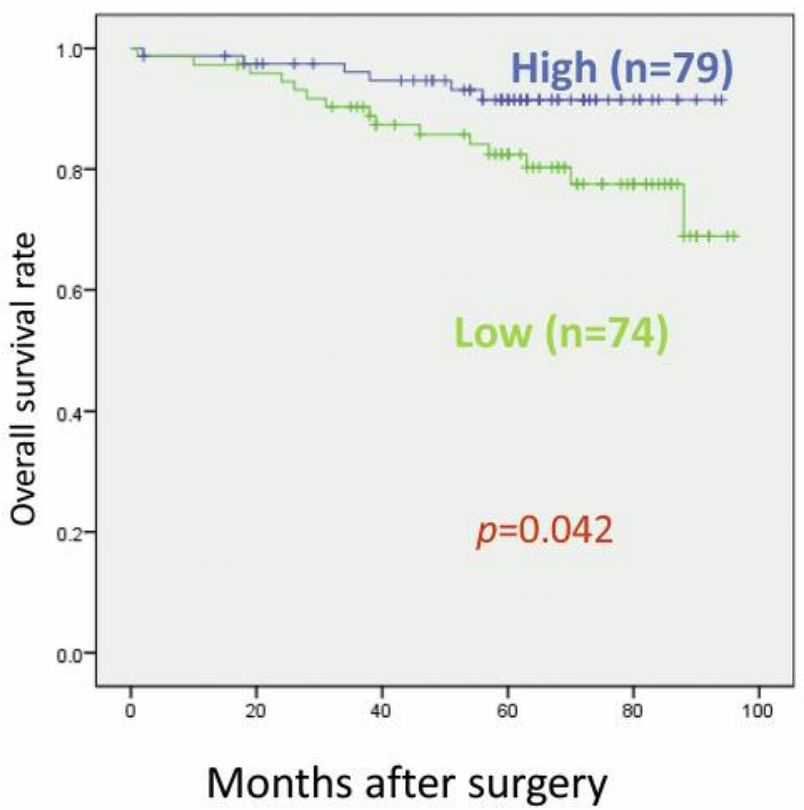

Figure 5. Relapse-free (a) and overall (b) survival curves of 153 patients with stage I-III colorectal cancer according to level of Quaking RNAbinding protein gene expression in tumor. p-Value from log-rank test.

were thereby divided into two groups based on tumor IRS: IRS <5.5: low expression group, IRS $\geq 5.5$ : high expression group. There were 75 patients in the low expression group and 81 patients in the high expression group.
The relationships between QKI expression and clinicopathological features. We analyzed the association between $Q K I$ expression level and age, gender, tumor location, histological type, depth of tumor invasion, lymph node metastasis, 
Table I. Candidate genes in colorectal cancer.

\begin{tabular}{|c|c|c|c|c|}
\hline Gene symbol & Probes & Gene name & Locus & Function (Ref) \\
\hline$Q K I$ & 212262_at & RNA binding protein Quaking & $6 q 26$ & Protein binding, splicing $(13,22-24,30)$ \\
\hline TIMP2 & 203167_at & TIMP metallopeptidase inhibitor 2 & $17 \mathrm{q} 25$ & Suppress the proliferation of endothelial cells (43) \\
\hline RET & 211421_s_at & Ret proto-oncogene & $10 \mathrm{q} 11.2$ & Transduce signals for cell growth and differentiation (44) \\
\hline TFPI2 & 209278_s_at & Tissue factor pathway inhibitor 2 & $7 \mathrm{q} 22$ & $\begin{array}{c}\text { Inhibit a variety of serine proteases, tumor suppressor, } \\
\text { alternative splicing }(45,46)\end{array}$ \\
\hline$K L F 4$ & 221841_s_at & Kruppel-like factor 4 & $9 \mathrm{q} 31$ & Tumor suppressor $(19,20)$ \\
\hline AKAP12 & 210517_s_at & A kinase (PRKA) anchor protein 2 & $9 \mathrm{q} 31.3$ & $\begin{array}{l}\text { Binds to the regulatory subunit of protein kinase A and } \\
\text { is found associated with the actin cytoskelaton (21) }\end{array}$ \\
\hline PEG3 & 209242_at & Paternally expressed 3 & $19 \mathrm{q} 13.4$ & $\begin{array}{l}\text { Alternative splicing cell proliferation and p-53-mediated } \\
\text { apoptosis, tumor suppressor (47) }\end{array}$ \\
\hline NT5E (CD73) & 203939_at & 5'-Nucleotidase,ecto (CD73) & $6 q 14-q 21$ & $\begin{array}{l}\text { A plasma membrane protein, determinant } \\
\text { of lymphocyte differentiation (48) }\end{array}$ \\
\hline RASSF2 & 203185_at & $\begin{array}{l}\text { Ras association (RalGDS/AF-6) } \\
\text { domain family member } 2\end{array}$ & $20 \mathrm{q} 13$ & Tumor suppressor (16-18) \\
\hline$G P X 3$ & 214091_s_at & Glutathione peroxidase 3 & $5 q 33.1$ & Tumor suppressor (49) \\
\hline UCHL1 & 201387_s_at & $\begin{array}{l}\text { Ubiquitin carboxyl-terminal } \\
\text { esterase L1 }\end{array}$ & $4 q 14$ & $\begin{array}{l}\text { A key role in proliferation, apoptosis and } \\
\text { metastasis of osteosarcoma cells }(50)\end{array}$ \\
\hline
\end{tabular}

lymphatic or venous invasion, distant metastasis, TNM stage, and recurrence rate after surgery. The relationships between $Q K I$ expression and clinicopathological features are summarized in Table III. A significant relationship was detected between low $Q K I$ expression and high recurrence rate ( $p=0.004$, chi-square test). We then investigated whether $Q K I$ expression was a predictor of tumor recurrence after surgery. The analysis of risk factors for postoperative recurrence in patients with stage I, II and III disease is shown in Table IV. Univariate analysis revealed that depth of tumor invasion $(p=0.004)$, lymph node metastasis $(p=0.001)$ and low $Q K I$ expression $(p=0.002)$ were possible risk factors for tumor recurrence after surgery. Multivariate analysis also showed that low $Q K I$ expression was an independent risk factor for tumor recurrence after surgery $(p=0.015)$. Furthermore, we found that low $Q K I$ expression was an independent risk factor in patients with stage II and III CRC ( $p=0.025)$ (data not shown). The 5year relapse-free survival (RFS) rate for stage I, II and III CRC with low and high $Q K I$ expression was $66.5 \%$ and $85.5 \%$, respectively. Patients with low tumor $Q K I$ expression had significantly shorter RFS than those with high $Q K I$ expression $(p=0.007)$ (Figure 5a). In addition, patients with low tumor $Q K I$ expression had significantly shorter overall survival than those with high $Q K I$ expression $(p=0.042)$ (Figure 5b).

\section{Discussion}

In this study, we carried out genome-wide expression screening in order to identify abnormally methylated genes in CRC with a potential role in tumorigenesis. From this analysis we chose to focus on the $Q K I$ gene, which encodes a RNA-binding protein that belongs to the signaling transduction and activation
Table II. Methylation status and mRNA expression in 115 patients with colorectal cancer.

\begin{tabular}{lccr}
\hline $\begin{array}{l}\text { QKI mRNA } \\
\text { expression }\end{array}$ & \multicolumn{2}{c}{ Methylation status } & \\
\cline { 2 - 3 } & Methylated & Unmethylated & Total \\
\hline Tumor<normal & 24 & 34 & 58 \\
Tumor>normal & 13 & 44 & 57 \\
Total & 37 & 78 & 115 \\
\hline
\end{tabular}

QKI: Quaking RNA-binding protein gene.

of RNA (STAR) family (24). Aberrant expression of the STAR proteins is associated with a number of developmental defects and human diseases $(25,26)$. $Q K I$ appears to be relevant to brain biology, as evidenced by its down-regulation in glioblastoma multiforme (27) and schizophrenia (28, 29). QKI produces a diverse set of proteins by alternative splicing (30), and is implicated in the regulation of cellular processes such as the cell cycle and differentiation (31), apoptosis (32), cell fate decisions, development and angiogenesis $(33,34)$. There is evidence that the tumor-suppressive actions of QKI are linked to: i) regulation of alternate splicing, for example, regulating the levels of alternate splice forms of the histone Macro-H2A1 (22), ii) stabilization of mir-20a, which regulates genes in the transforming growth factor $\beta$ pathway (23) and iii) regulation of splicing in lung cancer and regulation of the NOTCH signaling pathway.

In the context of CRC, $Q K I$ is thought to be a tumorsuppressor gene that functions as a principal regulator of the 
Table III. Relationship between Quaking RNA-binding protein gene expression and clinicopathological factors.

\begin{tabular}{|c|c|c|c|}
\hline Factor & $\begin{array}{c}\text { Low } \\
\text { expression } \\
(\mathrm{n}=75)\end{array}$ & $\begin{array}{c}\text { High } \\
\text { expression } \\
(\mathrm{n}=81)\end{array}$ & $p$-Value* \\
\hline \multicolumn{4}{|c|}{ Age at surgery (median $=68$ years) } \\
\hline$\geq$ Median & 39 & 37 & \multirow[t]{2}{*}{0.480} \\
\hline$<$ Median & 36 & 44 & \\
\hline \multicolumn{4}{|l|}{ Gender } \\
\hline Male & 49 & 50 & \multirow[t]{2}{*}{0.686} \\
\hline Female & 26 & 31 & \\
\hline \multicolumn{4}{|l|}{ Location } \\
\hline Colon & 45 & 53 & \multirow[t]{2}{*}{0.551} \\
\hline Rectum & 30 & 28 & \\
\hline Right-sided colon & 21 & 21 & \multirow[t]{2}{*}{0.731} \\
\hline Left-sided colon & 54 & 60 & \\
\hline \multicolumn{4}{|l|}{ Histological type } \\
\hline Well-differentiated & 32 & 28 & \multirow[t]{2}{*}{0.268} \\
\hline Not well-differentiated & 43 & 53 & \\
\hline \multicolumn{4}{|l|}{ Tumor depth of invasion } \\
\hline $\mathrm{T} 1,2$ & 12 & 23 & \multirow[t]{2}{*}{0.070} \\
\hline $\mathrm{T} 3,4$ & 63 & 58 & \\
\hline \multicolumn{4}{|l|}{ Lymph node metastasis } \\
\hline Absent & 43 & 55 & \multirow[t]{2}{*}{0.207} \\
\hline Present & 32 & 26 & \\
\hline \multicolumn{4}{|l|}{ Distant metastasis } \\
\hline Absent & 74 & 79 & \multirow[t]{2}{*}{0.614} \\
\hline Present & 1 & 2 & \\
\hline \multicolumn{4}{|l|}{ Lymphatic invasion } \\
\hline Absent & 28 & 32 & \multirow[t]{2}{*}{0.831} \\
\hline Present & 47 & 49 & \\
\hline \multicolumn{4}{|l|}{ Venous invasion } \\
\hline Absent & 13 & 14 & \multirow[t]{2}{*}{0.963} \\
\hline Present & 62 & 67 & \\
\hline \multicolumn{4}{|l|}{ TNM stage } \\
\hline I, II & 42 & 55 & \multirow[t]{2}{*}{0.152} \\
\hline III, IV & 33 & 26 & \\
\hline \multicolumn{4}{|l|}{ Recurrence after surgery } \\
\hline Absent & 52 & 72 & \multirow{2}{*}{$0.004 *$} \\
\hline Present & 23 & 9 & \\
\hline
\end{tabular}

$* \chi^{2}$ test.

differentiation of colon epithelium, and a suppressor of carcinogenesis by coordinately targeting multiple genes associated with cell growth and differentiation. Yang et al. found that QKI expression was greatly reduced in or absent from CRC cells, and down-regulation of QKI was associated with deregulation of $\beta$-catenin and $\mathrm{p} 27^{\mathrm{kip} 1}$ signaling (13). Hence, the down-regulation of $Q K I$ expression in the colon may be involved in cancer onset and progression (13). Consistent with this possibility, we found that low QKI expression occurred in about $47.4 \%$ of CRC specimens, and multivariate analysis showed that low $Q K I$ expression was an independent risk factor for tumor recurrence after surgery. Furthermore, the RFS and overall survival of patients with stage I, II and III CRC with low $Q K I$ expression was significantly shorter than those with high $Q K I$ expression.

Yang et al. reported that $Q K I$ down-regulation in some CRCs was at least partially due to promoter hypermethylation. Indeed, consistent with this suggestion, we found that $Q K I$ was one of the candidate genes for which mRNA expression levels were increased after demethylation treatment. $Q K I$ mRNA expression levels were significantly decreased in tumor tissues in which promoter methylation was detected compared with normal tissues $(p=0.049)$. Interestingly, the link that we identified between $Q K I$ promoter methylation and reduced $Q K I$ mRNA expression in CRC, is distinct from the mechanisms underlying $Q K I$ deregulation in glioma $(27,35)$, suggesting that the regulation of $Q K I$ expression is context specific, and diverse aberrations have an impact on $Q K I$ expression in cancer cells.

We did not detect a relationship between $Q K I$ protein expression measured by immunostaining and $Q K I$ promoter methylation status (data not shown). One possible explanation for this unexpected result is that there might be another pathway regulating $Q K I$ expression.

This study showed that low $Q K I$ expression was an independent risk factor for tumor recurrence after surgery, and patients with low $Q K I$ expression had a significantly poorer prognosis than those with high $Q K I$ expression. Postoperative adjuvant chemotherapy for patients with stage III CRC is internationally accepted as standard care for improving survival (36). For stage II CRC, the major Western guidelines recommend adjuvant chemotherapy when patients have risk factors including T4 lesions, fewer than 12 lymph nodes examined, perforation, poorly differentiated histology, and lymphovascular involvement, even though the efficacy of adjuvant chemotherapy for stage II CRC remains controversial (37-39). Our results suggest that patients with stage II and III CRC with low $Q K I$ expression are at highrisk for recurrence after surgery and might be candidates for adjuvant chemotherapy. In addition, if methylation-related mechanisms contribute to the inactivation of $Q K I$, demethylation could be an appropriate therapeutic strategy. Recent studies have shown the clinical efficacy of demethylating agents in the treatment of patients with hematological malignancies (40-42).

In conclusion, our study revealed that methylation of the $Q K I$ promoter and concomitant reduced expression of $Q K I$ mRNA may be important for CRC initiation and progression. In addition, patients with tumors expressing low levels of QKI experienced significantly higher rates of tumor recurrence after curative surgery and had worse prognoses. Our results suggest that low $Q K I$ expression may be a useful clinical biomarker for predicting recurrence and prognosis. Further validation or prospective studies are needed to assess the clinical utility of $Q K I$ as a biomarker. 
Table IV. Analysis of risk factors for postoperative recurrence in 153 patients with stage IIII colorectal cancer.

\begin{tabular}{|c|c|c|c|c|c|}
\hline \multirow[b]{2}{*}{ Factor } & \multicolumn{2}{|c|}{ Univariate analysis } & \multirow[b]{2}{*}{$p$-Value } & \multicolumn{2}{|c|}{ Multivariate analysis } \\
\hline & Recurrence $(n=31)$ & No recurrence $(n=122)$ & & HR $(95 \%$ CI $)$ & $p$-Value \\
\hline \multicolumn{6}{|c|}{ Age at surgery (median $=68$ years) } \\
\hline$\leq$ Median & 14 & 59 & 0.750 & & \\
\hline$>$ Median & 17 & 63 & & & \\
\hline \multicolumn{6}{|l|}{ Gender } \\
\hline Male & 19 & 78 & 0.785 & & \\
\hline Female & 12 & 44 & & & \\
\hline \multicolumn{6}{|l|}{ Location } \\
\hline Colon & 16 & 79 & 0.178 & & \\
\hline Rectum & 15 & 43 & & & \\
\hline \multicolumn{6}{|l|}{ Histological type } \\
\hline Well-differentiated & 11 & 48 & 0.693 & & \\
\hline Not well-differentiated & 20 & 74 & & & \\
\hline \multicolumn{6}{|l|}{ Tumor depth } \\
\hline $\mathrm{T}=1,2$ & 1 & 88 & 0.004 & $4.004(0.94716 .936)$ & 0.059 \\
\hline $\mathrm{T}=3,4$ & 30 & 34 & & & \\
\hline \multicolumn{6}{|l|}{ Lymph node metastasis } \\
\hline Absent & 12 & 85 & 0.001 & $2.453(1.237-4.863)$ & 0.010 \\
\hline Present & 19 & 37 & & & \\
\hline \multicolumn{6}{|l|}{ Lymphatic invasion } \\
\hline Absent & 10 & 50 & 0.374 & & \\
\hline Present & 21 & 72 & & & \\
\hline \multicolumn{6}{|l|}{ Venous invasion } \\
\hline Absent & 3 & 24 & 0.192 & & \\
\hline Present & 28 & 98 & & & \\
\hline \multicolumn{6}{|l|}{$Q K I$ expression } \\
\hline Low & 23 & 51 & 0.002 & $2.158(1.052-4.439)$ & 0.036 \\
\hline High & 8 & 71 & & & \\
\hline
\end{tabular}

QKI: Quaking RNA-binding protein gene, HR: hazard ratio, CI: confidence interval.

\section{Acknowledgements}

The Authors thank Y. Takagi, S. Kishiro and J. Inoue for their excellent technical assistance.

\section{References}

1 Jemal A, Ward E and Thun M: Declining death rates reflect progress against cancer. PLoS One 5: e9584, 2010.

2 Baylin SB and Jones PA: A decade of exploring the cancer epigenome - biological and translational implications. Nat Rev Cancer 11: 726-734, 2011.

3 Timp W and Feinberg AP: Cancer as a dysregulated epigenome allowing cellular growth advantage at the expense of the host. Nat Rev Cancer 13: 497-510, 2013.

4 Jones PA and Laird PW: Cancer epigenetics comes of age. Nat Genet 21: 163-167, 1999.

5 Lao VV and Grady WM: Epigenetics and colorectal cancer. Nat Rev Gastroenterol Hepatol 8: 686-700, 2011.

6 Kondo T, Furuta T and Mitsunaga K: Genomic organization and expression analysis of the mouse $Q k i$ locus. Mamm Genome 10: 662-669, 1999.
7 Esteller M: Cancer epigenomics: DNA methylomes and histonemodification maps. Nat Rev Genet 8: 286-298, 2007.

8 Wong JJ, Hawkins NJ and Ward RL: Colorectal cancer: a model for epigenetic tumorigenesis. Gut 56: 140-148, 2007.

9 Lippman Z, Gendrel AV, Colot V and Martienssen R: Profiling DNA methylation patterns using genomic tiling microarrays. Nat Methods 2: 219-224, 2005.

10 Tompa R, McCallum CM, Delrow J, Henikoff JG, van Steensel $\mathrm{B}$ and Henikoff S: Genome-wide profiling of DNA methylation reveals transposon targets of CHROMOMETHYLASE3. Curr Biol 12: 65-68, 2002.

11 van Engeland M, Derks S, Smits KM, Meijer GA and Herman JG: Colorectal cancer epigenetics: complex simplicity. J Clin Oncol 29: 1382-1391, 2011.

12 Carmona FJ and Esteller M: Epigenomics of human colon cancer. Mutat Res 693: 53-60, 2010.

13 Yang G, Fu H, Zhang J, Lu X, Yu F, Jin L, Bai L, Huang B, Shen L, Feng Y, Yao L and Lu Z: RNA-binding protein quaking, a critical regulator of colon epithelial differentiation and a suppressor of colon cancer. Gastroenterology 138: 231240.e231-235, 2010.

14 Ishiguro M, Iida S, Uetake H, Morita S, Makino H, Kato K, Takagi Y, Enomoto M and Sugihara K: Effect of combined 
therapy with low-dose 5-aza-2'-deoxycytidine and irinotecan on colon cancer cell line HCT-15. Ann Surg Oncol 14: 1752-1762, 2007.

15 Tanaka S, Arii S, Yasen M, Mogushi K, Su NT, Zhao C, Imoto I, Eishi Y, Inazawa J, Miki Y and Tanaka H: Aurora kinase B is a predictive factor for the aggressive recurrence of hepatocellular carcinoma after curative hepatectomy. Br J Surg 95: 611-619, 2008.

16 Hesson LB, Wilson R, Morton D, Adams C, Walker M, Maher ER and Latif F: $\mathrm{CpG}$ island promoter hypermethylation of a novel Ras-effector gene RASSF $2 A$ is an early event in colon carcinogenesis and correlates inversely with $K$-RAS mutations. Oncogene 24: 3987-3994, 2005.

17 Akino K, Toyota M, Suzuki H, Mita H, Sasaki Y, Ohe-Toyota M, Issa JP, Hinoda Y, Imai $\mathrm{K}$ and Tokino T: The Ras effector RASSF 2 is a novel tumor-suppressor gene in human colorectal cancer. Gastroenterology 129: 156-169, 2005.

18 Nosho K, Yamamoto H, Takahashi T, Mikami M, Taniguchi H, Miyamoto N, Adachi $\mathrm{Y}$, Arimura $\mathrm{Y}$, Itoh F, Imai $\mathrm{K}$ and Shinomura Y: Genetic and epigenetic profiling in early colorectal tumors and prediction of invasive potential in pT1 (early invasive) colorectal cancers. Carcinogenesis 28: 13641370, 2007.

19 Zhao W, Hisamuddin IM, Nandan MO, Babbin BA, Lamb NE and Yang VW: Identification of Krüppel-like factor 4 as a potential tumor-suppressor gene in colorectal cancer. Oncogene 23: 395-402, 2004.

20 Lee HY, Ahn JB, Rha SY, Chung HC, Park KH, Kim TS, Kim NK and Shin SJ: High KLF4 level in normal tissue predicts poor survival in colorectal cancer patients. World J Surg Oncol 12: 232, 2014.

21 Liu W, Guan M, Su B, Ye C, Li J, Zhang X, Liu C, Li M, Lin Y and $\mathrm{Lu} \mathrm{Y:} \mathrm{Quantitative} \mathrm{assessment} \mathrm{of} \mathrm{AKAP12} \mathrm{promoter}$ methylation in colorectal cancer using methylation-sensitive high resolution melting: Correlation with Duke's stage. Cancer Biol Ther 9: 862-871, 2010.

22 Novikov L, Park JW, Chen H, Klerman H, Jalloh AS and Gamble MJ: QKI-mediated alternative splicing of the histone variant MacroH2A1 regulates cancer cell proliferation. Mol Cell Biol 31: 4244-4255, 2011.

23 Chen AJ, Paik JH, Zhang H, Shukla SA, Mortensen R, Hu J, Ying H, Hu B, Hurt J, Farny N, Dong C, Xiao Y, Wang YA, Silver PA, Chin L and Vasudevan S: STAR RNA-binding protein Quaking suppresses cancer via stabilization of specific miRNA. Genes Dev 26: 1459-1472, 2012.

24 Vernet C and Artzt K: STAR, a gene family involved in signal transduction and activation of RNA. Trends Genet 13: 479-484, 1997.

25 Chénard CA and Richard S: New implications for the QUAKING RNA binding protein in human disease. J Neurosci Res 86: 233-242, 2008.

26 Richard S: Reaching for the stars: Linking RNA binding proteins to diseases. Adv Exp Med Biol 693: 142-157, 2010.

27 Li ZZ, Kondo T, Murata T, Ebersole TA, Nishi T, Tada K, Ushio $\mathrm{Y}$, Yamamura $\mathrm{K}$ and Abe $\mathrm{K}$ : Expression of $H q k$ encoding a $\mathrm{KH}$ RNA binding protein is altered in human glioma. Jpn J Cancer Res 93: 167-177, 2002.

28 Aberg K, Saetre P, Jareborg N and Jazin E: Human QKI, a potential regulator of mRNA expression of human oligodendrocyte-related genes involved in schizophrenia. Proc Natl Acad Sci USA 103: 7482-7487, 2006.
29 Haroutunian V, Katsel P, Dracheva S and Davis KL: The human homolog of the $Q K I$ gene affected in the severe dysmyelination "quaking" mouse phenotype: downregulated in multiple brain regions in schizophrenia. Am J Psychiatry 163: 1834-1837, 2006.

30 Kondo Y and Issa JP: Epigenetic changes in colorectal cancer. Cancer Metastasis Rev 23: 29-39, 2004.

31 Yang G, Lu X, Wang L, Bian Y, Fu H, Wei M, Pu J, Jin L, Yao $\mathrm{L}$ and $\mathrm{Lu} \mathrm{Z}$ : E2F1 and RNA binding protein QKI comprise a negative feedback in the cell cycle regulation. Cell Cycle 10: 2703-2713, 2011.

32 Pilotte J, Larocque D and Richard S: Nuclear translocation controlled by alternatively spliced isoforms inactivates the QUAKING apoptotic inducer. Genes Dev 15: 845-858, 2001.

33 van Mil A, Grundmann S, Goumans MJ, Lei Z, Oerlemans MI, Jaksani S, Doevendans PA and Sluijter JP: MicroRNA-214 inhibits angiogenesis by targeting Quaking and reducing angiogenic growth factor release. Cardiovasc Res 93: 655-665, 2012.

34 Noveroske JK, Lai L, Gaussin V, Northrop JL, Nakamura H, Hirschi KK and Justice MJ: Quaking is essential for blood vessel development. Genesis 32: 218-230, 2002.

35 Ichimura K, Mungall AJ, Fiegler H, Pearson DM, Dunham I, Carter NP and Collins VP: Small regions of overlapping deletions on $6 \mathrm{q} 26$ in human astrocytic tumours identified using chromosome 6 tile path array-CGH. Oncogene 25: 1261-1271, 2006.

36 de Gramont A, Chibaudel B, Bachet JB, Larsen AK, Tournigand $\mathrm{C}$, Louvet $\mathrm{C}$, André $\mathrm{T}$ and GERCOR (French Oncology Research Group): From chemotherapy to targeted therapy in adjuvant treatment for stage III colon cancer. Semin Oncol 38: 521-532, 2011.

37 National Comprehensive Cancer Network. NCCN Clinical Practice Guidelines in Oncology. Colon Cancer. Version 3. http:// www.nccn.org/professionals/physician_gls/pdf/colon.pdf, 2013.

38 Benson AB, Schrag D, Somerfield MR, Cohen AM, Figueredo AT, Flynn PJ, Krzyzanowska MK, Maroun J, McAllister P, Van Cutsem E, Brouwers M, Charette M and Haller DG: American Society of Clinical Oncology recommendations on adjuvant chemotherapy for stage II colon cancer. J Clin Oncol 22: 3408$3419,2004$.

39 Schmoll HJ, Van Cutsem E, Stein A, Valentini V, Glimelius B, Haustermans K, Nordlinger B, van de Velde CJ, Balmana J, Regula J, Nagtegaal ID, Beets-Tan R. G, Arnold D, Ciardiello F, Hoff P, Kerr D, Köhne C. H, Labianca R, Price T, Scheithauer W, Sobrero A, Tabernero J, Aderka D, Barroso S, Bodoky G, Douillard JY, El Ghazaly H, Gallardo J, Garin A, Glynne-Jones R, Jordan K, Meshcheryakov A, Papamichail D, Pfeiffer P, Souglakos I, Turhal S and Cervantes A: ESMO Consensus Guidelines for management of patients with colon and rectal cancer. a personalized approach to clinical decision making.Ann Oncol 23: 2479-2516, 2012.

40 Kantarjian H, Issa JP, Rosenfeld CS, Bennett JM, Albitar M, DiPersio J, Klimek V, Slack J, de Castro C, Ravandi F, Helmer R, Shen L, Nimer SD, Leavitt R, Raza A and Saba H: Decitabine improves patient outcomes in myelodysplastic syndromes: results of a phase III randomized study. Cancer 106: 1794-1803, 2006.

41 Kantarjian HM, Thomas XG, Dmoszynska A, Wierzbowska A, Mazur G, Mayer J, Gau JP, Chou WC, Buckstein R, Cermak J, Kuo C. Y, Oriol A, Ravandi F, Faderl S, Delaunay J, Lysák D, Minden $\mathrm{M}$ and Arthur C: Multicenter, randomized, open-label, 
phase III trial of decitabine versus patient choice, with physician advice, of either supportive care or low-dose cytarabine for the treatment of older patients with newly diagnosed acute myeloid leukemia. J Clin Oncol 30: 2670-2677, 2012.

42 Garcia-Manero G, Jabbour E, Borthakur G, Faderl S, Estrov Z, Yang H, Maddipoti S, Godley LA, Gabrail N, Berdeja JG, Nadeem A, Kassalow L and Kantarjian H: Randomized openlabel phase II study of decitabine in patients with low- or intermediate-risk myelodysplastic syndromes. J Clin Oncol 31: 2548-2553, 2013.

43 Furtado Y, Almeida G, Silveira FA, Silva KS, Maldonado P, do Val IC, Cavalcanti S, L MA and Carvalho MaG: TIMP2 gene methylation in cervical precursor and invasive lesions. Exp Mol Pathol 98: 119-123, 2015.

44 Hedayati M, Yeganeh MZ, Sheikholeslami S and Afsari F: Diversity of Mutations in the RET proto-oncogene and its oncogenic mechanism in medullary thyroid cancer. Crit Rev Clin Lab Sci: 1-35, 2015.

45 Chu X, Zhao P, Lv Y and Liu L: Decreased expression of TFPI-2 correlated with increased expression of CD133 in cholangiocarcinoma. Int J Clin Exp Pathol 8: 328-336, 2015.

46 Xu C, Wang H, He H, Zheng F, Chen Y, Zhang J, Lin X, Ma D and Zhang H: Low expression of TFPI-2 associated with poor survival outcome in patients with breast cancer. BMC Cancer 13: 118, 2013.
47 Nye MD, Hoyo C, Huang Z, Vidal AC, Wang F, Overcash F, Smith JS, Vasquez B, Hernandez B, Swai B, Oneko O, Mlay P, Obure J, Gammon MD, Bartlett JA and Murphy SK: Associations between methylation of paternally expressed gene 3 (PEG3), cervical intraepithelial neoplasia and invasive cervical cancer. PLoS One 8: e56325, 2013.

48 Zhang B, Song B, Wang X, Chang XS, Pang T, Zhang X, Yin K and Fang GE: The expression and clinical significance of CD73 molecule in human rectal adenocarcinoma. Tumour Biol 36: 5459-5466, 2015.

49 Qi X, Ng KT, Lian QZ, Liu XB, Li CX, Geng W, Ling CC, Ma YY, Yeung WH, Tu WW, Fan ST, Lo CM and Man K: Clinical significance and therapeutic value of glutathione peroxidase 3 (GPx3) in hepatocellular carcinoma. Oncotarget 5: 11103-11120, 2014.

50 Zheng S, Qiao G, Min D, Zhang Z, Lin F, Yang Q, Feng T, Tang L, Sun Y, Zhao H, Li H, Yu W, Yang Y, Shen Z and Yao Y: Heterogeneous expression and biological function of ubiquitin carboxy-terminal hydrolase-L1 in osteosarcoma. Cancer Lett 359: 36-46, 2015. 